SH
691
T2G7

CASE B

THE TARPON $\mathrm{BY}$

F. GRAY GRISWOLD 
ENERAL IERARY NIVERSITY OF CALIFORNIA

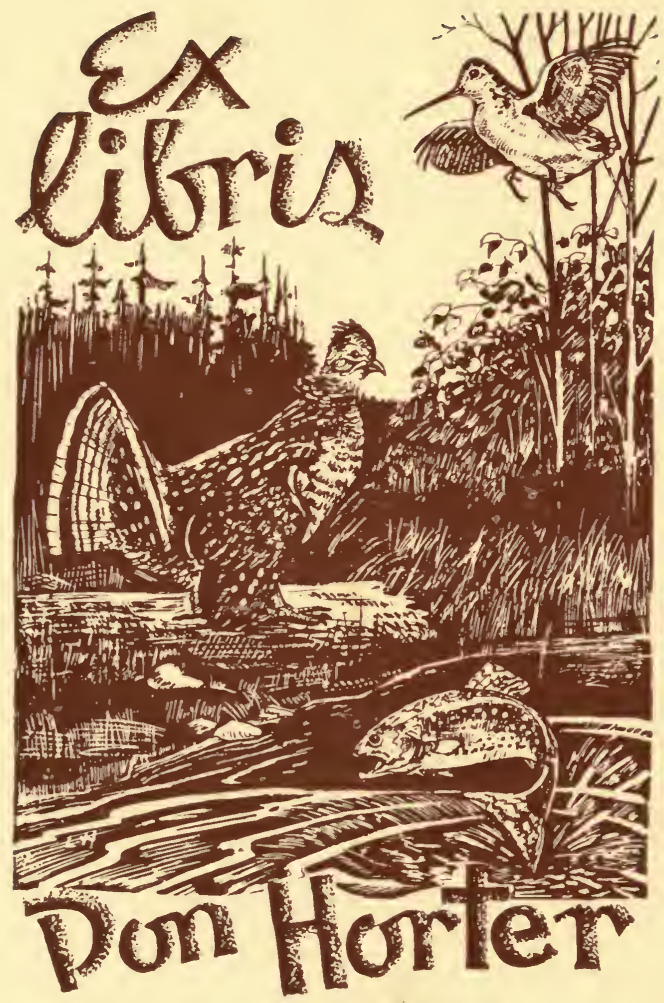


The Sporting Gallery AND BoOKSHOP, INC.

No. 38, East 52nd Street, New York 
Digitized by the Internet Archive in 2007 with funding from Microsoft Corporation 


\title{
THE TARPON
}

\author{
C OMPLIMENTS OF \\ F. GRA Y GRIS W O L D
}





\section{THE TARPON BY}

F. GRAY GRISWOLD

\section{NEW YORK}

PRIVATELY PRINTED

1922 
CASE

B 


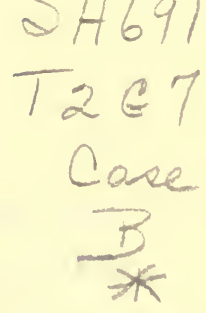

\section{THE TARPON \\ (Tarpon Atlanticus)}

THIS game fish has the local names of 1 Tarpon, Tarpum, Grand Ecaille, Savalo, Sabalo, Savanilla, Savalle, Silver Fish, and Silver King.

He belongs to the family of Elopidea, and is the largest of the herring tribe. His habitat at sea is in the warmavaters of the Atlantic Ocean and of the Gulf Stream. He is found along the coasts of Brazil and Central America, as well as among the islands of the West Indies and also along the gulf coast of Mexico. In the summer time tarpon are numerous all around the Gulf of Mexico and on the east coast of Florida.

A few fish have been known to appear in midsummer as far north as the New England coast. I have seen some in the New York Aquarium that had been taken in nets in New York Bay. In the summer of 1919, I saw a fine 
specimen that was caught in a net in Narragansett Bay near Newport.

Little is known of the habits of the tarpon when in the open sea. I never met them at sea but once, and that was in the month of February along the edge of the Gulf Stream off New River Inlet. On that occasion I sailed through a large school on the surface swimming south.

Tarpon are often taken in the nets off Hillsboro Inlet, which is not far from where I met them.

They arrive among the Keys of lower Florida in small schools of an average weight in February, and from then on their numbers increase until midsummer. These schools of fish dwell in Bahia Hondo, Matecumbe Sound and other channels for a few days before working their way into the Gulf of Mexico. If a Norther blows they go to sea, and return later. Other fish enter the rivers of the east coast of Florida.

The building of the East Coast Railway greatly disturbed their customs, for many of the fairways they were in the habit of journeying through were closed by trestles and viaducts. At that time schools of fish appeared in Biscayan Bay, and many were taken off the 
mouth of Arch Creek. These fish were evidently looking for a passage through to the west coast, having found their usual route further south barred by the railroad.

On the west coast tarpon are to be found in Shark, Harney, Broad, Turner's and Losman's rivers, and among the Thousand Islands. In Surveyor's Creek, Estero, and the Caloosahatchee River, also in the Passes that divide the outer islands such as Captiva and Boca Grande, and up along the Gulf of Mexico.

These fish are supposed to return south in early November, but many remain in the deep holes of the rivers during the winter and do not show unless the water is at least as warm as 68 degrees.

Where these fish come from is not known, but they appear to arrive from the West Indies via the Gulf Stream.

There is another migration up the west side of the Gulf that appears to come from the rivers of Mexico. They begin to arrive at Aransas Pass in March.

It is not known where they spawn. Some people believe it happens at sea but, from what I have seen, I believe they spawn in brackish water at the headwaters of streams, or at the 
head of the tide, for it is there only that you find small fish.

Fifteen miles up rivers in Cuba I have taken large tarpon that were evidently spent fish, not only from their appearance but because they had little strength. It is possible they also spawn on the flats and sandbars inside the outer islands.

Tarpon are very susceptible to the cold, and love warm water. When in the rivers and not looking for food they will lie on the bottom, coming up from time to time for a mouthful of air and then retiring to their resting place, after which air-bubbles will arise to the surface.

It is this action that makes the natives insist that these fish have lungs and use them for breathing. Then again they will lie on the bottom for hours as other fish do, with little or no motion of the fins.

I once saw quite a school of large tarpon lying on the bottom in the Los Angeles River in the Isle of Pines. They took no notice of the launch, although we passed over them twice in seven feet of clear water.

I once caught a baby tarpon five inches long in a gill net in New River. He was badly gilled, yet lived all day in a tub. He did not act as 
other fish do, but allowed me to stroke him gently and, tarpon-like, showed no.fear. From time to time he would rise to the surface as the large fish do in the rivers, then go to the bottom of the tub again, and in a moment the bubbles would slowly issue from his mouth.

The long lower jaw of the tarpon shows that he is a bottom feeder, and lives on crabs; yet he also feeds on school fish such as mullet, needle fish, and the like.

Although the tarpon's mouth is as hard as stone, there is a very sensitive cuticle that covers the roof of the mouth. When you see a tarpon in' a river jump you may be sure that a crab has nipped this cuticle. When they jump in the sea it may be done to get rid of ramoras.

I believe that the tarpon not only come to the rivers of Florida in the spring and early summer for the purpose of spawning, but that like the salmon they return to the same river as a rule, and that many fish remain in deep holes in the rivers throughout the winter.

This belief is based on the fact that in the late 80 's and early 90 's there were many tarpon to be found in the Peace River. During the freeze in 1894 many hundreds of tarpon were 
killed by the cold in this stream. The banks were lined with dead fish of the largest kind. Since that time, few tarpon are to be found in the Peace River.

I was in Florida at the time of the "Big Freeze," living in a houseboat on the St. Lucie River. The mercury went to 18 degrees, and the river water steamed and smoked. It was not the cold that directly killed the fish, but the cold seemed to have consumed the oxygen in the water, for the fish died from asphyxiation.

For two hundred miles both shores of the shallow Indian River were banked with dead fish, mostly so-called surface feeders such as snook, bluefish, and the like. The bottom fish did not seem to be affected.

I saw many bluefish of five pounds flopping along on the surface, but no mullet. These wise fish went to sea in schools the day before the Norther arrived.

We picked up nineteen green turtles that were benumbed by the cold and floating on the surface. These turtles were stacked on the lower deck of the houseboat and revived much to the consternation of the crew, although they were compensated for their troubles the following day 
when they disposed of the turtles at Fort Pierce for $\$ 200$.

I have fished for tarpon in the St. Lucie River in midwinter. For days you would not see any fish, but if you waited until after a few days of hot sun had warmed the water to 68 degrees they would begin to roll and show themselves and would then take live silver mullet bait.

It took me some time to find out how to keep mullet alive, for if you put them into a well in a boat they bruise their noses against the sides of the well and die.

I procured oat bags and laced barrel hoops around them on the outside. I then ran drawing strings around the mouths of the bags. After placing half a dozen live mullet, taken by cast-net, in each of several bags I practised with them to find out in what depth of water the mullet were most comfortable. I then tied the bags to the roots of trees along the bank of the stretch of river I proposed to fish. In this manner I always had fresh, live bait at my. convenient disposal.

I found the new moon was the best day of the month to fish. One winter, on the new moon in January, I took a 187-pound tarpon; 
and on the following new moon, in February, I landed a fish weighing 165 pounds.

This fishing was done from a row boat; but in later years and since the advent of the Wilson spoon I have fished in a small launch. A live bait behind a launch soon dies and revolves like a pin-wheel which destroys one's line, but the Wilson spoon skitters and does not revolve in the water.

Tarpon are greatly attracted by this spoon, and it has been a blessing to me in Cuba where no mullet were to be had.

I built two fishing yachts, the Savalo and the Kona, for tarpon fishing in Cuba, and fished there almost every winter from 1904 to 1920 .

I have cruised from Nipe Bay to the westward around Cape San Antonio and as far as Cienfuegos on the south coast, and also to the Isle of Pines 60 miles south of Cuba.

Tarpon are to be found in certain rivers in Cuba at all times of the year. I say certain rivers, for the tarpon is a clean fish and does not favor muddy water. The soil of Cuba is red and rich, so that the streams that drain the cultivated lands are mostly muddy; in such rivers no tarpon are to be found.

There are large swamps in Cuba, and the 
rivers that drain these swamps run clear. It is in these rivers that the most fish are to be found.

The Rio Negro and Jatibonico drain over one hundred square miles of swamp, and in these rivers the tarpon abound.

The Damuji River is also a river of fairly clear water, and at times there is good fishing there.

These rivers are all on the south coast of Cuba. On the north coast a small river with a long name, the Zaraguanacan, is often full of tarpon.

The fish do not seem to go above the tide. The limit of the mangroves, which do not grow along fresh water, seems to be the limit of the tarpon from what I have seen, yet Mr. Zane Grey says he found tarpon one hundred miles up the Panuco River in Mexico.

The fish do not run as large as at some places in Florida, although I have taken fish of 130 pounds in weight and have lost heavier ones. The headwaters of the rivers abound in small fish. I have at times seen hundreds of tarpon that would weigh from 10 to 15 pounds and have taken them four inches long.

On one occasion I found a narrow stretch of the Jatibonico River simply alive with 15 -pound 
tarpon. I landed 14 in an hour's fishing and must have "jumped" 25 more fish. At another time and in another river I "jumped" 52 large tarpon in three days' fishing of the flood tides.

My fishing journal tells me that I landed 254 tarpon in Cuba, which means that I must have hooked over 1,000 fish, for it is not possible to save more than one hooked tarpon out of five fish hung on a Wilson spoon. The weight of the spoon helps the fish to free himself.

I invariably turned the hooked fish loose unless they were damaged. They sometimes bruise their gills in jumping and bleed profusely. In such cases the fish will not live if liberated.

The natives of Cuba spear tarpon and I am sorry to say net the small ones. Both there and in Mexico the fish are eaten fresh as well as salted.

My method of fishing in Cuba has been trolling a large sized Wilson spoon with sixty feet of line over the stern of a small launch. The launch travels at the rate of four miles an hour. If a fish is hooked in a wide part of the river $I$ have the launch circle the fish. It is easy to land a 100-pound tarpon in 8 minutes by this method if you understand fighting fish.

If a fish is hooked in a narrow stream it is 
necessary to keep the boat away from the fish until he is well spent. In narrow streams you lose many fish for they jump into the overhanging branches of the mangrove trees which line the banks and tumble back into the water leaving your tackle entangled among the branches.

The Cauto on the south coast is the only river in Cuba that is navigagable. The other streams are often from eight to ten feet deep, excepting where they flow into the sea; here you will find wide bars with but four feet of water.

It is a delight to fish in these rivers in winter for there are no sharks to rob you of your fish nor any insects of any kind excepting a few mosquitoes at sunset if your yacht happens to be five or ten miles up a river and moored to the windward bank. The rivers are lined with mangroves and dotted here and there along the banks with royal palms, the most beautiful of trees.

Of this tree Davis wrote: "The royal palm is the characteristic feature of the landscape in Cuba. It is the most beautiful of all palms and possibly the most beautiful of trees. The cocoanut palm, picturesque as it is, has a pathetic resemblance to a shabby feather duster and its 
trunk bends and twists as though it had not the strength to push its way through the air and to hold itself erect. But the royal palm shoots up boldly from the earth with the grace and symmetry of a marble column."

At sunset the small white cranes and egrets fly upstream to their roosts. They flit along close to the surface of the river and it is amusing to watch the tarpon rise at their shadows as they fly by.

There is a pond of brackish water on Pine Island, Florida, which has no outlet to the sea and contains many quite small tarpon. The spawn must have been dropped by birds or carried to the pond on the backs of alligators. Owing to the poor food these fish do not increase in size.

I do not take any interest in fishing for tarpon with so-called light tackle. I believe a 15-thread line is quite light enough and that the "punishment should fit the crime." In other words the charm of heavy fishing is being "up against" a big fish and landing him as quickly and as humanely as possible. The chief pleasure is the give and take between man and fish.

The theory that fish are cold-blooded creatures and therefore do not suffer is all very well as a 
theory but I never want any fish to dangle at the end of my line and eventually commit suicide.

What anglers mean when they tell stories of fighting a salmon for an hour or longer is beyond me. Any salmon up to 45 pounds in weight ought to be killed in twenty minutes even with light grilse tackle if the angler knows how to fish.

Fishing with a 16-ounce grilse rod I once rose, hooked, landed and weighed in 50 minutes, 5 salmon that weighed 128 pounds. This was not done with intent but in the regular course of fishing.

What I do believe in is fishing for tarpon with a plain reel without any drag. The science of tarpon fishing was lost when the reel drag was invented. It came about in the following manner:

The science of sea fishing was first developed along the Atlantic seaboard in the early 60's and the Striped Bass (Roccus lineatus) was the interesting fish which started this development.

The multiplying reels and Cuttyhunk twisted linen lines were invented for this purpose, it being discovered that these fish were too quick for the old single action reels and that the braided cotton lines were not strong enough to hold these active, agile fish. 
The method of fishing was casting a bait into the white tumbling surf from the rocks or from stands built for that purpose.

The three jointed rods of ash or lancewood used at first were later abandoned, for two-piece rods of Japan or Calcutta bamboo, and these rods were later developed into the two-piece split bamboos with guides and tips of agate of the present day.

The reels had no drag but were supplied with a musical click of small value. Later on in the 80 's a light drag was placed on the left side of the reel for tarpon fishing, to prevent the line from over-running in case of carelessness.

The first tarpon fishermen were old bass fishermen who had learned the trick of playing heavy fish with rod and reel and they all fished with the right thumb on the reel as it had been their custom so to fish when casting.

A few of us took up tarpon fishing without ever having done much bass fishing and we fished with the left thumbs on the reels and pumped the fish with our right hands.

This method had a great advantage for the right hand was always free, away from the reel handle and out of danger, yet always ready to reel in the slack. 
The man who attempted to check a fish with his right thumb on the reel and then reel in the slack with his right hand was always in danger of the back lash of the reel handle.

E. H. Vom Hofe, the celebrated tackle manufacturer, was one of the first and most successful tarpon fishermen, and, being an expert bass fisherman as well, always fished with his right thumb on the reel.

We often discussed the two ways of fishing and I could not persuade him that my way was right and his way was wrong until one day as he was playing a heavy fish at Captiva Pass the reel handle broke his right thumb.

The Rabbeth drag had already been invented but was taboo according to the Tuna Club Rules, so Vom Hofe sat up nights until he had perfected the reel drag as we know it to-day.

He showed it to me and I had the first reel made with the new invention. He described it to me at the time as a "reel with which a man can fish who has no thumbs at all." (1902).

Later on the B-Ocean reel was adapted by Mr. Boschen, the greatest fisherman of all time, with a free running spool and stationary handle for heavy sword-fishing, for this fish takes sudden dives of two hundred feet and more and if 
you cannot quickly free the line your rod is pulled out of your hands or broken.

The tackle as it exists to-day is capable of holding and landing a 1,000-pound game fish and the reels will hold 1,200-feet of 24-thread line.

The drag is necessary for swordfish, marlin, and giant tuna, for you cannot fight such heavy fish for four and more hours with thumb pressure only, but for tarpon and tuna up to 200 pounds in weight thumb pressure is quite sufficient and much more sportsmanlike.

I killed 5 tuna that weighed 491 pounds in six hours with a plain reel and have landed very many tarpon weighing from 187 pounds down without any reel drag, so I write of my own personal experience.

With the invention of the reel drag the science of tarpon fishing received a coup de grâce. It is no longer fishing but "coffee grinding" and the fish have no chance whatever.

I have seen men at Boca Grande block the line at the first jump of a tarpon, start the launch engine and tow the fish ashore with his mouth wide open.

That is not fishing; it is murder!

Tarpon can readily be killed on light tackle, 
only it takes more line and more time and the rod enjoys most of the fun.

With light tackle you must follow the fish, with heavy tackle the fish comes to you. As hooked tarpon always float with the tide or current it is at times hard work, but when you hear of a fisherman who has been an hour or more killing a tarpon you may be quite certain he has been trying to pull the heavy fish against the tide.

The Light Tackle Club at Aransas Pass died a natural death, for many members have told me they gave up going there because they wearied of light tackle yet did not like to go back to the only real sport, heavy tackle.

Mr. L. G. Murphy holds the Aransas Pass record for light tackle, a tarpon 6 feet $9 \frac{3}{4}$ inches long.

At Catalina Island a marlin of 185 pounds and a tuna weighing $14: \frac{1}{2}$ pounds have been landed with light tackle by Mr. Jump. This is done by setting the drag at the proper tension so that a long run of the fish will not break the line. The angler holds the handle of the reel which works but one way when the drag is on. The fish takes the line from the reel with the set drag and the fisherman reels in the slack when he 
can get it. It takes skill, time, and patience but to me it does not give the satisfaction of being "up against" a big fish.

If the advocates of light tackle for tarpon would go back to the plain reel instead I can promise them plenty of exercise and entertainment.

I am greatly interested in all fish and have a real affection for the tarpon. He is a gentleman among fishes. $\mathrm{He}$ is not in the least afraid of man or boat and when once hooked does not attempt to run away or take advantage of his great strength.

His one idea is to get rid of the hook which annoys him and he will jump clear of the surface many times and attempt to free himself. If these tactics fail he will then swim close up to the boat, raise himself out of the water and shake his head. It is then that he is usually lost.

$\mathrm{He}$ is the grandest and most beautiful silver fish that swims and he has the best manners of any of the denizens of the deep, for he avoids all snags, stumps, or obstructions in a river when hooked and never takes advantage of the fisherman but fights square.

I have the greatest admiration for this Silver King of sea fishes. 


\section{METHODS OF TARPON FISHING}

The first tarpon were taken bottom fishing. It was the custom to anchor the boat at some chosen spot that was frequented by the fish and then to chum with pieces of cut mullet. Two hooks baited with the better part of a mullet on each hook were cast out. The angler watched one rod and his guide took charge of the other.

I always took pains that my rod pointed towards the spot where my bait lay so that when the latter was picked up the line would run free from the reel. The fish was allowed to take fifty feet of line before striking because a tarpon will pick up a bait and move off with it in his mouth before gorging it.

The theory that loose line must be coiled in the bottom of the boat was for novices that could not pick up a rod without checking the fish.

Tarpon that have gorged the bait, unless hooked in a vital spot, fight much harder than those that are hooked in the mouth. 
The drawback to bottom fishing was that the fish were all destroyed and could not be set free.

The snoods were made of deerskin or cotton cord partly for the reason that wire is stiff and the fish would drop such a bait and also that if a shark picked up the bait he would bite through the snood and free himself.

I always used snoods made of three strands of fine wire twisted. They were not so easily seen, were pliable and took more fish, besides I enjoyed playing the mackerel sharks for they are great jumpers and strong fighters.

When the Van Vleck hook was invented the general method of fishing changed. It had been discovered that when trolling the greater part of the fish were hooked over the incisors which are very large in the tarpon and that the fish would jump and throw the hook. Mr. Van Vleck had hooks made with the belly nearer the point of the hook, which made it more difficult for the fish to get rid of the hook when jumping.

I say this hook was invented, yet I have seen in the Naples Museum, the very same hook found in Pompeii (destroyed A. D. 79) and probably used for trolling for tunney-fish.

We then either trolled for tarpon or anchored in strong tideways in the Passes with a strip of 
mullet for bait and with one hundred feet of wet line. When a tarpon was hooked your guide would throw the buoyed anchor rope overboard and you would follow the fish. Having your anchor buoyed saved time and it also gave you a reserved position to return to.

When Mr. Mygatt discovered Boca Grande as a fishing possibility (1898), owing to the great depth of water there drift fishing was adopted.

The leader used is of heavy strong piano wire six feet in length and at the upper or rod end of the leader a sinker is fastened to the swivel or ring with a light piece of string. The hook. is baited with a live blue crab or a strip of mullet. The launch goes under power to the entrance to the Pass and drifts in with the tide. The fisherman keeps the hook off the bottom, in other words slowly trolls the bait close to the bottom where the tarpon lie.

As the depth of water changes, the length of line is changed. If you hook a fish his first jump frees the sinker. The drawback to this fishing is that the sharks are numerous and steal the hooked fish.

To my mind this is the most uninteresting form of tarpon fishing, for to hook a fish near the bottom in 60 feet of water does not give the 
same sensation as travelling along at four miles an hour and hooking near the surface, a fish that immediately leaps in the air. A tarpon will also jump twice as often in 8 feet of water.

I have seen forty or more boats drifting fairly close together at Boca Grande on a moonlit night and consternation caused among them by the sudden jumping of two or three large hooked fish.

It is a popular and lazy form of sport where fish are plentiful, and as the tarpon is an elusive fish and difficult to find, Boca Grande is much frequented for the fish are known to be there in numbers.

To me the great charm of tarpon fishing is to hunt for the fish and find them, which you can do in rivers as they often swim along the surface, or if lying on the bottom come up from time to time for air.

Fish hooked in the mouth can readily be set free. Your guide is provided with a large barbless release-hook which he inserts in the fish's jaw and then removes the fishhook with his gloved hand.

The season for tarpon fishing in Florida is from the month of May to October.

At Aransas Pass, Texas, they fish in the Gulf 
outside the jetties with live or dead silver mullet. The drawbacks are the rough water and the numerous sharks. June and October are the best months.

When I was at Tampico, Mexico, the method of fishing was trolling a dead silver mullet behind a row boat. We fished at the jetties seven miles below the town or ten miles up the Panuco River above Tampico. There is also a Laguna that contains small tarpon. Owing to the trade wind, afternoon fishing is difficult. The best months are February and March.

In the Panama Zone the fishing is done from the shore below the spillway of the Gatun Dam. The method of fishing is with the fly and the season is from May to November. If the Canal had no locks the tarpon would now be in the Pacific as well as in the Atlantic Ocean. 


\section{ADVICE}

When going seafishing I always choose from the new to the full moon, for fish feed at night when there is a moon, and are therefore less hungry than after dark nights.

This does not apply to Boca Grande where the moon is necessary for night fishing.

The days of the changes of the moon, espe cially the first day of the new moon, are the best days during the month for tarpon fishing. The probable reason for this is that the tides are high and strong at such times, which means more food or more inclination to feed, for the new moon increases the activity of all fish.

When on a fishing trip I never dry my lines. Salt water preserves linen lines and a wet line is stronger than a dry one. The lines must be thoroughly dried indoors at the end of a fishing trip. Never dry lines in the sun or wind for they are fatal. Lines used in fresh water must be dried daily.

After a day's fishing unreel the line and reel 
it on again with care. This is done to take the strain off the reel-drum and to prevent the reel from spreading.

Split bamboo rods are the only rods that are strong and durable enough for heavy fishing. For ease and comfort fish with a rod that is not over six inches longer than you are tall. Long rods are back breakers.

When I first visited Catalina Island in 1900 I broke at the butt, a defective $6 \mathrm{ft} .9$ in. rod, which, when repaired, was $6 \mathrm{ft} .5$ in. long. With this rod I killed 13 tuna that weighed 1,411 pounds in fourteen days and discovered the advantage of a short rod. I now fish with split-bamboo rods in one piece, tip and butt all in one, $6 \mathrm{ft} .5$ in. long.

My success at Catalina in 1900 was the cause of the Tuna Club Rules. The Secretary of the Club informed me as I was leaving the island that they had desired that an experienced tarpon fisherman should try the tuna but that they were disappointed with my "great success!"

The Tuna Club Rules followed. They were quite right to limit the size and strength of lines but an angler should be allowed to choose his own length of rod. It takes better hands to fish with a short stiff rod than with a long 
pliable one and in heavy fishing comfort and ease is the desideratum.

If the insects are bad use:

\section{C's}

Oils of Camphor, Cedar and Citronella in equal parts. For the bites of insects Pine Oil is the best palliative. If subject to sunburn "Face Paint" is an absolutely sure preventative. It makes one look like a Red Indian but it is pleasant to use and no sun has the slightest effect on skin covered with this mixture.

Prescription for Face Paint to Prevent Sunburn

3 oz. Yellow Ochre

2 oz. Burnt Sienna

$4 \mathrm{oz}$. Mucilage of Quince or Flax Seed, or bandoline, Rosewater, to make one pint. Shake well before using.

Put in a large-mouthed bottle and apply with absorbent cotton and when nearly dry, spread evenly over the face with the fingers. 


\section{WEIGHT AND MEASUREMENT}

Mr. William H. Wood, the pioneer of tarpon fishing, was the originator of the formula for estimating the weight of tarpon when first taken from the water:

$$
\frac{\text { Girth }^{2} \mathrm{x} \text { length }}{800}=\text { weight }
$$

I was puzzled for a long time trying to discover the reason for the divisor being 800. A friendly fellow fisherman, Mr. B. R. Kittredge, eventually solved the question as follows:

"Consider in the first place that the shape of the fish is represented by two wedges placed base to base. The area of the base of a wedge multiplied by half its length gives its cubic volume. So the volume of the two wedges would be the area of the base multiplied by the length of one wedge. The volume of a fish in cubic inches would be the area of his middle section multiplied by half his length.

If you square the circumference of any given square you obtain a square that is 16 times the area of the given square. For example $10 \times 10$ 
has an area of 100. It has a circumference of 40 which squared gives 1,600. So that the square of the girth of a fish divided by 16 would give the area of that section of the fish. Multiply the area of this section by half his length and you will have the cubic volume of the fish.

Formula: $\frac{\text { Girth }^{2}}{16} \times \frac{\text { length }}{2}=$ cubic volume

The specific gravity of fish is approximately 1.15 so that about 25 cubic inches of fish weigh 29 of water or one pound.

So that if you divide the number of cubic inches in a fish by 25 you will have his weight in pounds:

Formula: $\frac{\text { Girth }^{2}}{16} \times \frac{\text { length }}{2} \times \frac{1}{25}=$ weight in lbs. which simplified is Girth ${ }^{2} \mathrm{x}$ length over 800 .

My friend says a more simple formula is: $\frac{1}{4}$ Girth $^{2} \times 2$ times length = weight.

Tarpon must be measured when first taken from the water in order to obtain their true weight for they shrink when exposed to the air. A heavy fish that is hung up over night will stretch inches in length by the following morning. The length should be measured from the tip of the closed mouth over the swell of the fish to a line drawn between the flukes of the tail. 


\section{RECORDS}

As far as my personal knowledge is concerned the first tarpon was landed with rod and reel by Mr. W. H. Wood on March 25th, 1885, bottom fishing in Surveyors' Creek, Florida. Mr. Wood's great ambition was to land a tarpon while fishing from the shore or beach.

I know of over a dozen fish that have been taken that weighed 200 pounds or more.

The first was landed by Mrs. Stagg and weighed, I believe, 205 pounds.

Edward Vom Hofe's fish followed on April 30, 1898, 210 pounds at Captiva Pass, Florida.

N. M. George took one of 213 pounds at Bahia Honda, Florida, on April 8th, 1901.

Dr. Howe wrote me from Mexico that he had captured a 223-pound tarpon at Tampico.

The largest tarpon I ever saw was caught off Tea Table Key, Florida, on May 15th, 1904. I was told that it weighed 224 pounds. Charlie Thompson, a professional fisherman, was the lucky angler.

W. A. McLaren holds the record for a fish 
taken in the Panuco River, Mexico, on March 27th, 1911. Length $7 \mathrm{ft} .8$ ins.; girth 47 ins. Weight 232 pounds.

Mrs. W. Ashby Jones caught a tarpon in the Caloosahatchee River, Florida, in 1916, that weighed 210 pounds.

Mr. B. W. Crowninshield has a record of 25 tarpon taken between sunrise and sunset at Boca Grande and I believe Mr. L. G. Murphy has a like record at Aransas Pass.

The greatest fishing I ever heard of was done by Mr. and Mrs. Magill on a cruise along the west coast of Florida in 1915. They captured 176 tarpon that weighed 16,377 pounds. The heaviest fish weighed $196 \frac{1}{2}$ pounds, eleven weighed over 180 and forty over 150 pounds each.

There were 785 tarpon weighed at Useppa Island in 1917 and but 23 of them weighed over 150 pounds.

At Aransas Pass, Texas, the following fish were liberated after being measured:

$1906 \ldots \ldots 1,573$

$1907 \ldots \ldots .1,333$

1908...... 700 Beginning of light tackle

$1909 \ldots \ldots .720$

$1910 \ldots \ldots .800 \quad 49 \%$ on light tackle 
$\begin{array}{llll}1911 \ldots \ldots \ldots & 718 & 66 \% & \text { on } \\ 1912 \ldots & \text { light tackle } \\ 1913 \ldots \ldots & 530 & 64 \% & \text { "6 }\end{array}$

The falling off between 1907 and 1908 was partly owing to the introduction of light tackle but also to the extension of the jetties which made the channel dangerous and rough.

In the 90's the tarpon that were weighed would average about 100 pounds but of late years the average has fallen to about 80 pounds. This would lead one to believe that the number of heavy fish is decreasing.

I believe that the tarpon of over 150 pounds in weight are of great age and that they grow very slowly. I judge this from the fact that they are dainty feeders, for there is very little undigested food found in them when examined.

Several thousand fish have been destroyed yearly for over twenty-five years and although it is now the custom to liberate most of the hooked fish many of these tired tarpon become the victims of piratical sharks and those that are taken in nets are usually destroyed by the fishermen owing to the damage they do to the nets. 


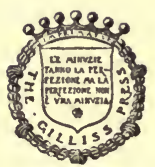




IL $1234 !$ 
1

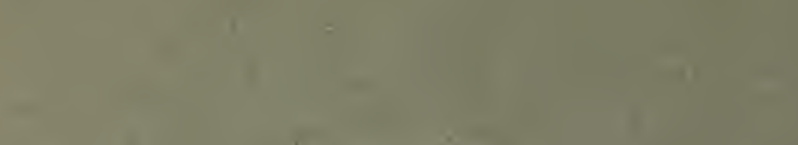

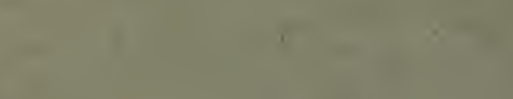

$+1$

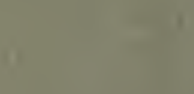

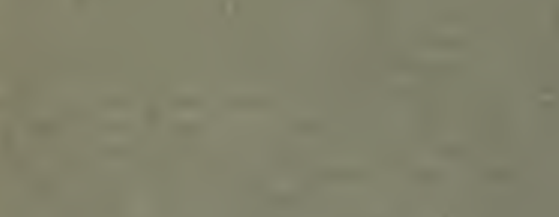

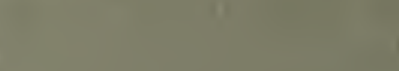

i

I

(1)

1)

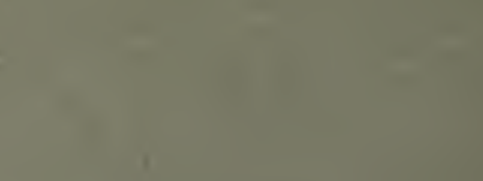

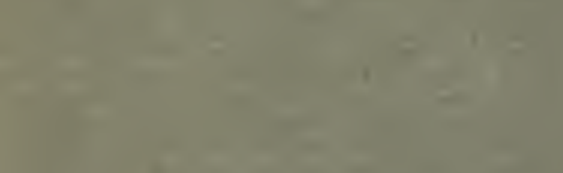

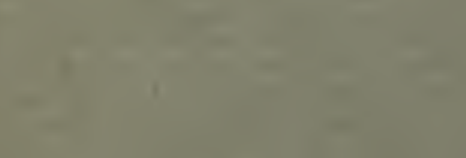

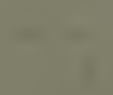

it

is

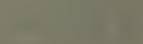

n.

,

1.

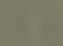

14

1.

Q⿻ivi

r

$+4$

-

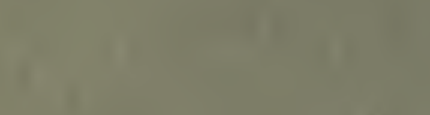

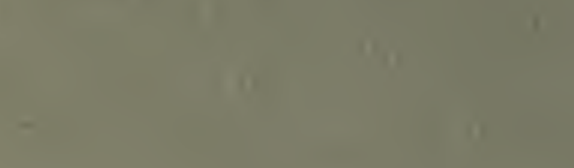

1

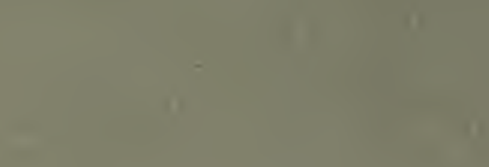

